Article

\title{
Three-Component Reaction of Tautomeric Amidines with 3-Ferrocenylmethylidene-2,4-pentanedione. Formation of Polymeric Coordination Complexes of Potassium Ferrocenyl-(hexahydro)pyrimidoxides
}

Elena I. Klimova ${ }^{1, *}$, Marcos Flores-Alamo ${ }^{1}$, Tatiana Klimova ${ }^{1}$, Sandra Cortez Maya ${ }^{1}$ and Irina P. Beletskaya ${ }^{2}$

1 Facultad de Química, Universidad Nacional Autónoma de México, Cd. Universitaria, Coyoacán, C.P. 04510, México D.F., Mexico

2 Chemistry Department, Lomonosov Moscow State University, Leninskie Gory, Moscow119899, Russia

* Author to whom correspondence should be addressed; E-Mail: eiklimova@yahoo.com.mx; Tel./Fax: +52-555622-5371.

Received: 8 October 2013; in revised form: 5 December 2013 / Accepted: 9 December 2013 / Published: 20 December 2013

\begin{abstract}
Acetamidine hydrochloride and $p$-aminobenzamidine dihydrochloride interact with 3-ferrocenylmethylidene-2,4-pentanedione at $80-82{ }^{\circ} \mathrm{C}$ in the presence of $\mathrm{K}_{2} \mathrm{CO}_{3}$ in the water-alcohol medium in two tautomeric forms (the amidoimine and enediamine ones) with formation of mixtures of pyrimidine and piperidone derivatives and polymeric coordination complexes of potassium ferrocenyl(hexahydro)pyrimidoxides. The structure of the resultant compounds is elucidated on the basis of $\mathrm{IR},{ }^{1} \mathrm{H}$ - and ${ }^{13} \mathrm{C}-\mathrm{NMR}$ spectroscopy, mass spectrometry and elemental analysis data. The crystal structures of 6-ferrocenyl-4-hydroxy-4-methyl-2-piperidone, potassium 6-ferrocenyl-4-methyl-2methylidene(hexahydro)pyrimidin-4-oxide and 2-(4-aminophenyl)-4-ferrocenyl-6-methylpyrimidine were determined by X-ray analysis of suitable single crystals.
\end{abstract}

Keywords: ferrocene; 3-ferrocenylmethylidene-2,4-pentanedione; amidines; ferrocenylpyrimidines; ferrocenylpiperidones; complexes of potassium ferrocenyl(hexahydro)pyramidin-4-oxides 


\section{Introduction}

Organic compounds of the ferrocene series evoke interest in view of their potential practical applications in diverse fields, such as organic and organometallic synthesis, coordination chemistry, materials science, homogeneous catalysis, supramolecular chemistry, chemo- and biosensors, medicinal chemistry, etc. [1-7]. Ferrocenyl-substituted nitrogen heterocycles are of special interest in the search for bioactive substances. Such compounds include ferrocenyl derivatives of pyrazolines, pyrazoles, triazoles, benzimidazoles, benzindazoles, quinuclidines, pyrimidines, etc. [8-15]. It is known that the presence of ferrocene groups in heterocyclic compounds usually enhances their pharmacological characteristics in comparison with substances of similar structure but without ferrocene substituents. Therefore, the keen interest in the synthesis of novel ferrocenyl-containing heterocycles is quite natural, especially if these compounds contain functional groups in heterocyclic rings.

We have recently reported the synthesis of ethyl-2-aryl(methyl)- and 2-amino-6-ferrocenyl(dihydro)pyrimidine-4-carboxylates with high anticarcinogenic activity [16] via the reaction between ethyl-2-acyl-3-ferrocenyl acrylates with amidines. Bioactive ferrocenyl(dihydro)pyrimidines with ethoxycarbonyl substituents in the heterocyclic nuclei were isolated with yields about $40 \%-45 \%$, together with the products of several side processes: fragmentations of the initial ethyl 2-acyl-3ferrocenyl acrylates, 1,3-insertion of amidines into ferrocenyl acrylates [16-18], etc. However, despite the comparatively low yields of ferrocenyl(dihydro)pyrimidines, the high bioactivity of the latter compounds evoked our interest in a more detailed investigation of the interaction between ferrocenylcontaining $\beta$-dicarbonyl compounds and nitrogen polynucleophiles.

\section{Results and Discussion}

\subsection{Reactions of Acetamidine and p-Aminobenzamidine with 3-Ferrocenylmethylidene-2,4-pentanedione}

This paper investigates the interaction of acetamidine hydrochloride (2) and $p$-aminobenzamidine dihydrochloride (3) with 3-ferrocenylmethylidene-2,4-pentanedione (1) in the presence of excess of $\mathrm{K}_{2} \mathrm{CO}_{3}$. Acetamidine and $p$-aminobenzamidine, which are formed from hydrochlorides $\mathbf{2}$ and $\mathbf{3}$ as a result of treatment with potassium carbonate in the water-alcohol medium used, must exist in two tautomeric forms: 2a and $\mathbf{2 b}, \mathbf{3 a}$ and $\mathbf{3 b}$ (Scheme 1), respectively. Thus, 3-ferrocenylmethylidene-2,4dione (1) must interact with each of the tautomeric forms $\mathbf{2} \mathbf{a}, \mathbf{2} \mathbf{b}$ and $\mathbf{3 a}, \mathbf{3 b}$ of the amidines.

Scheme 1. Tautomeric forms of the acetamidine (2a, 2b) and $p$-aminobenzamidine (3a, $3 \mathbf{b})$.

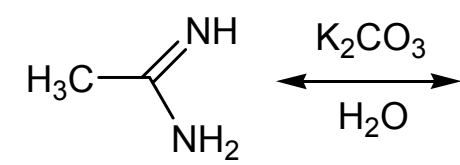

$2 a$

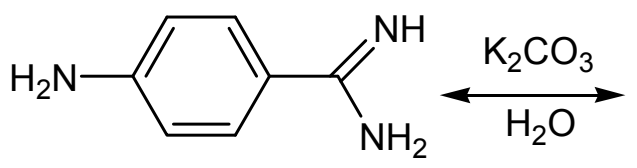

$3 \mathbf{a}$<smiles>C=C(N)N</smiles>

$2 \mathbf{b}$

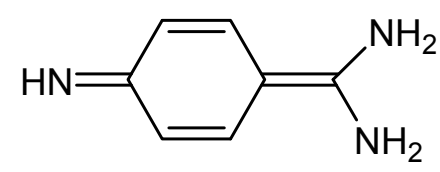

$3 \mathbf{b}$ 
Indeed, we have found that 1,3-diketone 1 reacts with acetamidines (2a,b) (water-alcohol medium, $\left.\mathrm{K}_{2} \mathrm{CO}_{3}, 80-85{ }^{\circ} \mathrm{C}\right)$, yielding a mixture of several products: 4-ferrocenyl-3-butenone (4, 25\%), 4-ferrocenyl-2,6-dimethylpyrimidine (5, 20\%), 6-ferrocenyl-4-hydroxy-4-methyl-2-piperidone (6, 23\%), and potassium 6-ferrocenyl-4-methyl-2-methylidene(hexahydro)pyrimidin-4-oxide (7, 17\%) (Scheme 2).

Compounds 4-7 were separated on a chromatographic column containing $\mathrm{Al}_{2} \mathrm{O}_{3}$ (Brockmann activity grade III). The first compound to leave the column is chalcone 4 (eluent: hexane-ether, 5:1), the next one is pyrimidine 5 (eluent: hexane-ether, 2:1), then hydroxypiperidone $\mathbf{6}$ (eluent: hexane- $\mathrm{CH}_{2} \mathrm{Cl}_{2}$, 2:1), and the last one to be washed out is potassium pyrimidoxide 7 (eluent: $\mathrm{CH}_{2} \mathrm{Cl}-\mathrm{CH}_{3} \mathrm{OH}-\mathrm{H}_{2} \mathrm{O}, 2: 2: 1$ ).

The structure of compounds 4-7 was elucidated on the basis of elemental analysis, mass spectrometry, ${ }^{1} \mathrm{H}$ and ${ }^{13} \mathrm{C}$-NMR spectroscopy data, as well as X-ray diffraction analysis of single crystals of compounds 6 and 7.

Scheme 2. Reaction of 3-ferrocenylmethylidene-2,4-pentanedione (1) with acetamidine (2a,b).

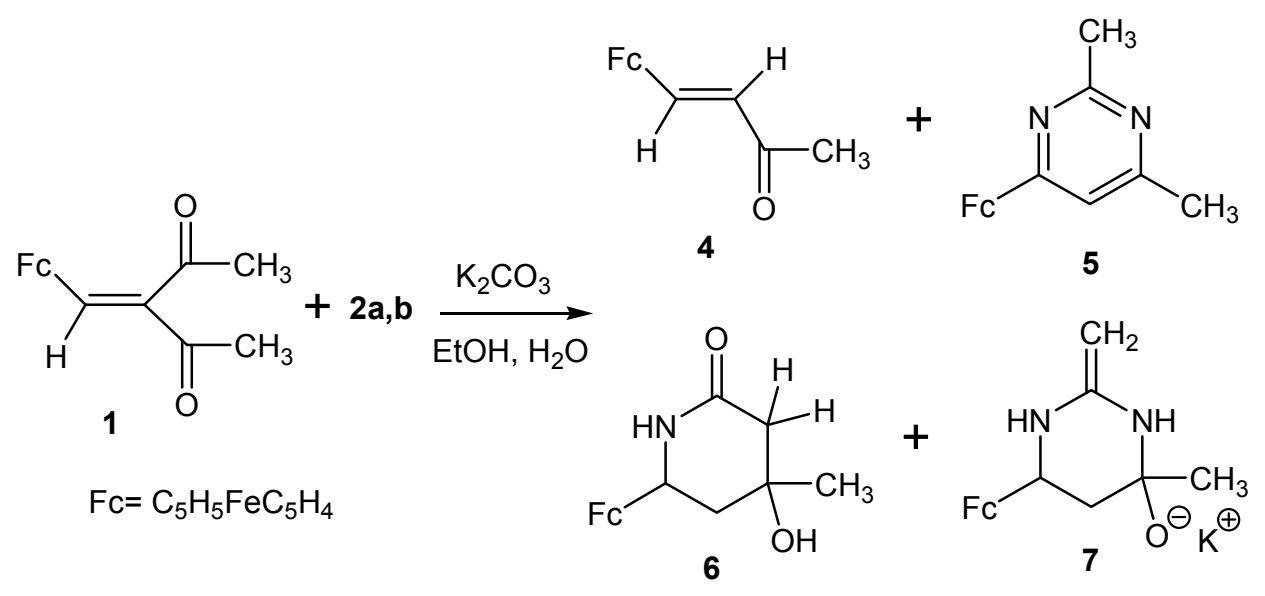

According to ${ }^{1} \mathrm{H}-\mathrm{NMR}$ findings, 4-ferrocenyl-3-butenone (4) is generated solely in the form of the trans-isomer according to the $J=15.9 \mathrm{~Hz}$ spin-spin coupling constant of the olefin protons. The ${ }^{1}$ H-NMR spectrum of ferrocenylpyrimidine 5 contains signals from hydrogen atoms of two methyl groups and one ferrocene substituent, as well as one singlet from the olefinic hydrogen atom of the heterocycle. Additionally, in the ${ }^{13} \mathrm{C}-\mathrm{NMR}$ spectrum of compound 5, there are three signals from the $\mathrm{C}_{1}, \mathrm{C}_{3}$ and $\mathrm{C}_{5}$ carbons of the heterocyclic ring and one signal from $\mathrm{C}_{\mathrm{ipso}} \mathrm{Fc}$, thus unambiguously confirming the structure of the resultant ferrocenylpyrimidine $\mathbf{5}$.

The structure of hydroxypiperidone 6 was established on the basis of IR, ${ }^{1} \mathrm{H}-\mathrm{NMR}$, and ${ }^{13} \mathrm{C}-\mathrm{NMR}$ spectroscopy. The IR spectrum of compound 6 contains characteristic absorption bands of the $\mathrm{NH}$, $\mathrm{OH}, \mathrm{C}=\mathrm{O}$, and $\mathrm{Fc}$ groups (see the Experimental section). The ${ }^{1} \mathrm{H}-\mathrm{NMR}$ spectrum contains signals from protons of one methyl and one ferrocene substituents, one hydroxyl group, one NH-fragment, two doublets from protons of the methylene fragment in the heterocycle, and also an $\mathrm{ABX}$ pattern of signals from protons of the $-\mathrm{CH}_{2}-\mathrm{CH}-$ fragment in the heterocycle. The ${ }^{13} \mathrm{C}-\mathrm{NMR}$ data also confirm the structure of compound $\mathbf{6}$.

In addition to spectral data, the spatial configuration of piperidone $\mathbf{6}$ was further confirmed by $\mathrm{X}$-ray diffraction analysis of single crystals obtained by crystallization from $\mathrm{CH}_{2} \mathrm{Cl}_{2}$. The general view of molecule 6 is shown in Figure 1, while the principal geometric parameters are listed in the Table 1. 
The six-membered cycle in structure $\mathbf{6}$ has a boat conformation, where the ferrocene and methyl substituents occupy the axial-equatorial positions.

Figure 1. X-ray crystal structure of 6.

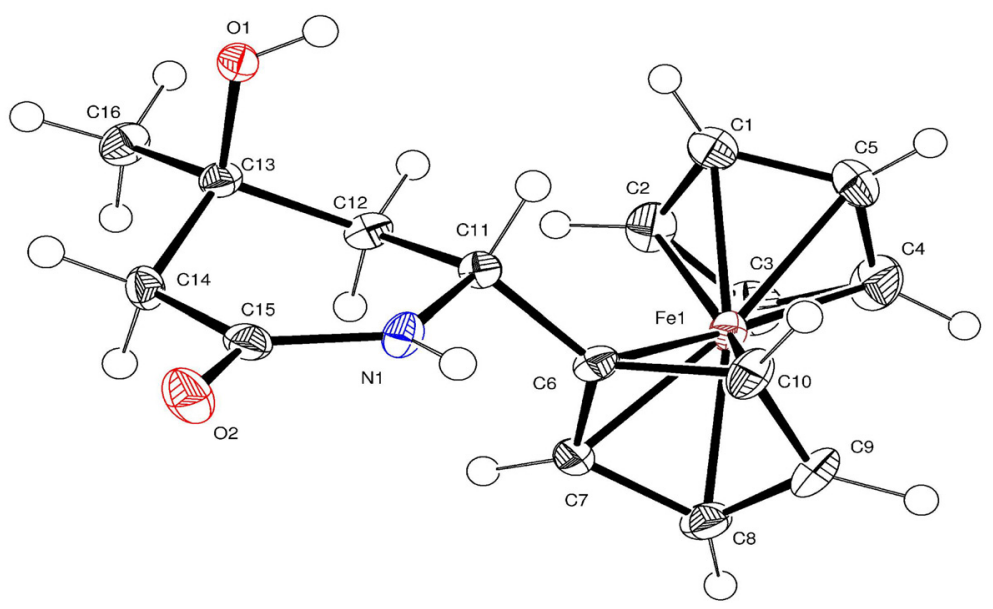

The structure of product 7 , isolated by chromatography with the use of water in the eluent, was determined according to the corresponding elemental analysis, mass spectrometry, IR, ${ }^{1} \mathrm{H}-\mathrm{NMR}$, and ${ }^{13} \mathrm{C}$-NMR spectroscopy data. According to these findings, molecule 7 contains the following fragments: $\mathrm{Me}, \mathrm{Fc}, \mathrm{CH}_{2}=, 2 \mathrm{NH}$ and $-\mathrm{CH}_{2}-\mathrm{CH}-$, in addition to two signals of quaternary carbons $(\delta=55.01,158.75)$ and one signal of $\mathrm{C}_{\mathrm{ipsoFc}}$.

Compound 7 is a water- and alcohol-soluble yellow crystalline substance, storage-stable in the crystalline form and in solutions, it decomposes during melting $\left(\sim 286^{\circ} \mathrm{C}\right)$, a property that is characteristic of ionic products. Using crystallization from aqueous methanol, we have managed to grow single crystals of 7 that were suitable for X-ray diffraction studies of the spatial structure of 7 . The general view of molecule 7 is shown in Figure 2, and the main geometrical parameters are listed in Table 1.

Figure 2. X-ray crystal structure of 7.

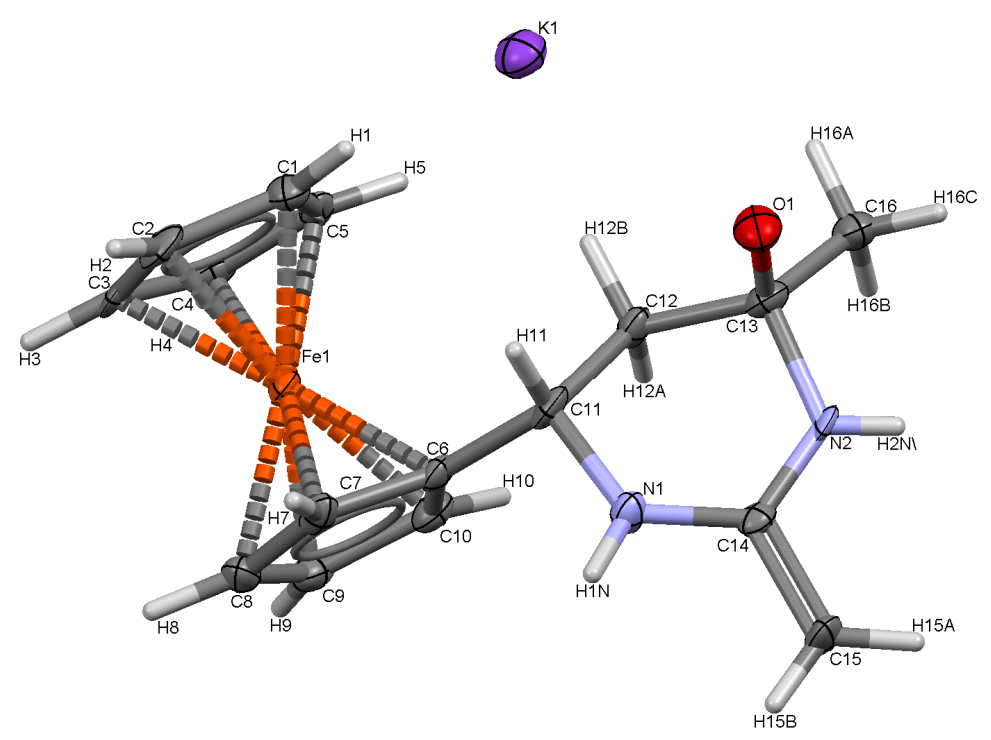


Table 1. Selected bond lengths and bond angles for compounds 6, 7 and $\mathbf{8}$.

\begin{tabular}{|c|c|c|c|}
\hline \multicolumn{2}{|c|}{ Selected bond lengths $(\AA ̊)$} & \multicolumn{2}{|c|}{ Selected bond angles $\left({ }^{\circ}\right)$} \\
\hline \multicolumn{4}{|c|}{6} \\
\hline $\mathrm{C}(11)-\mathrm{N}(1)$ & $1.476(3)$ & $\mathrm{N}(1)-\mathrm{C}(11)-\mathrm{C}(12)$ & $111.22(19)$ \\
\hline $\mathrm{C}(11)-\mathrm{C}(12)$ & $1.520(3)$ & $C(13)-C(12)-C(11)$ & $113.77(18)$ \\
\hline $\mathrm{C}(12)-\mathrm{C}(13)$ & $1.517(3)$ & $\mathrm{O}(1)-\mathrm{C}(13)-\mathrm{C}(12)$ & $111.54(19)$ \\
\hline $\mathrm{C}(13)-\mathrm{O}(1)$ & $1.439(3)$ & $\mathrm{O}(1)-\mathrm{C}(13)-\mathrm{C}(14)$ & $105.81(18)$ \\
\hline $\mathrm{C}(15)-\mathrm{N}(1)$ & $1.329(3)$ & $C(12)-C(13)-C(14)$ & $108.05(19)$ \\
\hline$C(13)-C(14)$ & $1.524(3)$ & $C(15)-C(14)-C(13)$ & $112.94(19)$ \\
\hline$C(14)-C(15)$ & $1.506(3)$ & $\mathrm{O}(2)-\mathrm{C}(15)-\mathrm{N}(1)$ & $121.3(2)$ \\
\hline $\mathrm{C}(15)-\mathrm{O}(2)$ & $1.247(3)$ & $\mathrm{N}(1)-\mathrm{C}(15)-\mathrm{C}(14)$ & $117.9(2)$ \\
\hline \multicolumn{4}{|c|}{7} \\
\hline $\mathrm{N}(1)-\mathrm{C}(11)$ & $1.482(6)$ & $\mathrm{N}(1)-\mathrm{C}(11)-\mathrm{C}(12)$ & $109.6(4)$ \\
\hline $\mathrm{C}(11)-\mathrm{C}(12)$ & $1.522(6)$ & $C(13)-C(12)-C(11)$ & $112.7(4)$ \\
\hline $\mathrm{C}(12)-\mathrm{C}(13)$ & $1.520(7)$ & $\mathrm{O}(1)-\mathrm{C}(13)-\mathrm{N}(2)$ & $105.1(4)$ \\
\hline $\mathrm{C}(13)-\mathrm{O}(1)$ & $1.418(6)$ & $\mathrm{O}(1)-\mathrm{C}(13)-\mathrm{C}(12)$ & $111.3(4)$ \\
\hline $\mathrm{C}(13)-\mathrm{N}(2)$ & $1.469(6)$ & $\mathrm{N}(2)-\mathrm{C}(13)-\mathrm{C}(12)$ & $106.8(4)$ \\
\hline $\mathrm{C}(14)-\mathrm{N}(2)$ & $1.305(6)$ & $\mathrm{N}(2)-\mathrm{C}(14)-\mathrm{N}(1)$ & $120.4(4)$ \\
\hline $\mathrm{C}(14)-\mathrm{N}(1)$ & $1.327(6)$ & $\mathrm{N}(2)-\mathrm{C}(14)-\mathrm{C}(15)$ & $120.5(4)$ \\
\hline $\mathrm{C}(14)-\mathrm{C}(15)$ & $1.487(6)$ & $\mathrm{N}(1)-\mathrm{C}(14)-\mathrm{C}(15)$ & 119.1(4) \\
\hline $\mathrm{O}(1)-\mathrm{K}(1)$ & $3.072(4)$ & $\mathrm{C}(13)-\mathrm{O}(1)-\mathrm{K}(1)$ & $119.5(3)$ \\
\hline $\mathrm{K}(1)-\mathrm{N}(1) \# 1$ & $3.136(4)$ & $\mathrm{O}(1)-\mathrm{K}(1)-\mathrm{N}(1) \# 1$ & $97.31(10)$ \\
\hline $\mathrm{N}(1)-\mathrm{K}(1) \# 1$ & $3.136(4)$ & $\mathrm{O}(1)-\mathrm{K}(1)-\mathrm{N}(2) \# 2$ & $138.86(11)$ \\
\hline $\mathrm{K}(1)-\mathrm{N}(2) \# 2$ & $3.147(5)$ & $\mathrm{N}(1) \# 1-\mathrm{K}(1)-\mathrm{N}(2) \# 2$ & $92.44(11)$ \\
\hline $\mathrm{N}(2)-\mathrm{K}(1) \# 3$ & $3.147(5)$ & $\mathrm{C}(14)-\mathrm{N}(2)-\mathrm{C}(13)$ & $123.1(4)$ \\
\hline$C(13)-C(16))$ & $1.502(7)$ & $C(14)-N(1)-K(1) \# 1$ & $117.0(3)$ \\
\hline $\mathrm{C}(1)-\mathrm{Fe}(1)$ & $2.044(5)$ & $\mathrm{C}(11)-\mathrm{N}(1)-\mathrm{K}(1) \# 1$ & $116.9(3)$ \\
\hline $\mathrm{N}(1)-\mathrm{H}(\mathrm{N} 1)$ & $0.91(5)$ & $C(14)-N(2)-K(1) \# 3$ & $121.2(3)$ \\
\hline $\mathrm{N}(2)-\mathrm{H}(\mathrm{N} 2)$ & $0.76(5)$ & $C(13)-N(2)-K(1) \# 3$ & $115.4(3)$ \\
\hline \multicolumn{4}{|c|}{8} \\
\hline $\mathrm{N}(1)-\mathrm{C}(11)$ & $1.347(5)$ & $\mathrm{N}(1)-\mathrm{C}(11)-\mathrm{C}(12)$ & $121.4(3)$ \\
\hline $\mathrm{C}(11)-\mathrm{C}(12)$ & $1.400(5)$ & $\mathrm{C}(13)-\mathrm{C}(12)-\mathrm{C}(11)$ & 116.9(3) \\
\hline $\mathrm{C}(12)-\mathrm{C}(13)$ & $1.389(6)$ & $\mathrm{N}(2)-\mathrm{C}(13)-\mathrm{C}(12)$ & $121.8(3)$ \\
\hline $\mathrm{C}(13)-\mathrm{N}(2)$ & $1.347(5)$ & $\mathrm{N}(2)-\mathrm{C}(13)-\mathrm{C}(21)$ & $117.5(3)$ \\
\hline $\mathrm{C}(14)-\mathrm{N}(2)$ & $1.340(5)$ & $\mathrm{N}(2)-\mathrm{C}(14)-\mathrm{N}(1)$ & $125.3(3)$ \\
\hline $\mathrm{C}(14)-\mathrm{N}(1)$ & $1.341(5)$ & $\mathrm{N}(2)-\mathrm{C}(13)-\mathrm{C}(15)$ & $118.7(3)$ \\
\hline $\mathrm{C}(14)-\mathrm{C}(15)$ & $1.470(5)$ & $\mathrm{C}(14)-\mathrm{N}(1)-\mathrm{C}(11)$ & $117.3(3)$ \\
\hline $\mathrm{C}(18)-\mathrm{N}(3)$ & $1.377(5)$ & $\mathrm{C}(14)-\mathrm{N}(2)-\mathrm{C}(13)$ & $117.2(3)$ \\
\hline
\end{tabular}

As follows from the results of this analysis, compound 7 has the structure of potassium 6-ferrocenyl-4-methyl-2-methylidene(hexahydro)pyrimidin-4-oxide. The central fragment of the molecule is a six-membered ring with two nitrogen atoms. A characteristic feature of the crystal structure of 7 is that the unit cell contains two molecules with oppositely oriented ferrocene fragments and methylene fragments oriented so as to be brought closer to each other (Figure 3). 
Figure 3. Structure of the fragment of unit cell of 7.

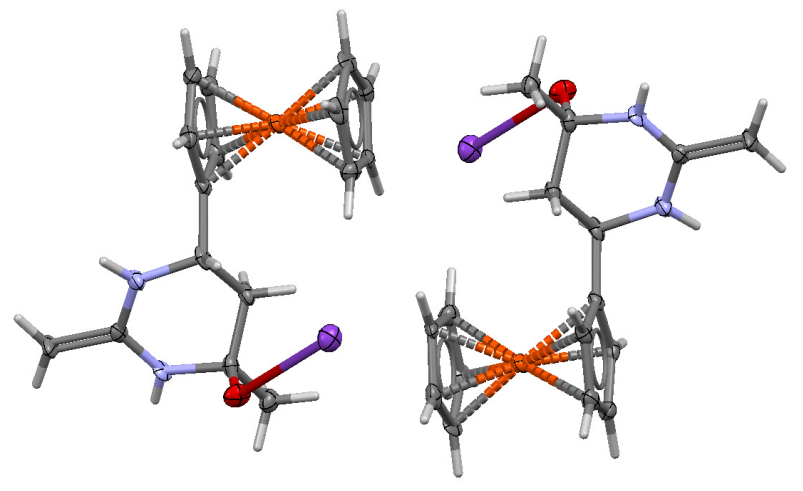

Figure 4 shows the nature of coordination interactions of the potassium cation with three adjacent molecules $\mathbf{7}$, forming the polymeric structure of compound 7 and determining its high stability.

Figure 4. Fragment of X-ray crystal structure of 7.

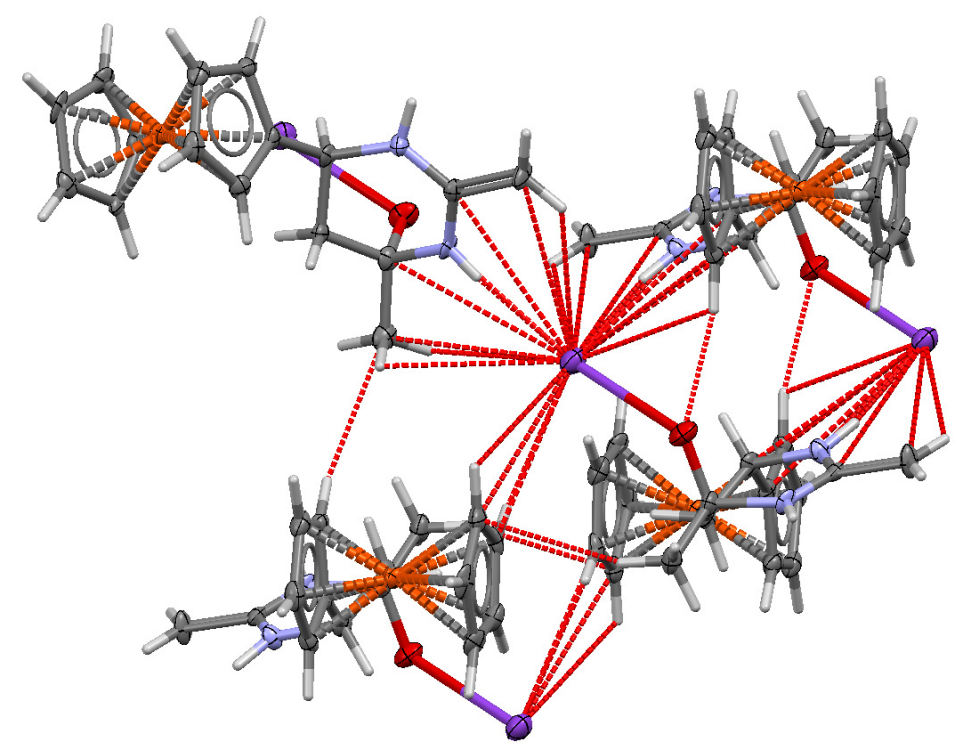

The interaction of 3-ferrocenylmethylidene-2,4-pentanedione (1) with 4-aminobenzamidine (3a,b) dihydrochloride $\left(\mathrm{EtOH} / \mathrm{H}_{2} \mathrm{O}, \mathrm{K}_{2} \mathrm{CO}_{3}, 80-82{ }^{\circ} \mathrm{C}\right)$ also leads to the formation of a mixture of several products: trans-4-ferrocenyl-3-butenone (4), 2-(4-aminophenyl)-4-ferrocenyl-6-methylpyrimidine (8), and three spiro compounds: 9, 10, and 11 (Scheme 3).

Compounds 4, 8-11 were separated using column chromatography $\left(\mathrm{Al}_{2} \mathrm{O}_{3}\right.$, grade III). The structure of each compound was determined on the basis of IR, ${ }^{1} \mathrm{H}$ and ${ }^{13} \mathrm{C}-\mathrm{NMR}$ spectra, mass spectra, and elemental analysis, which are described in the Experimental section.

$\mathrm{X}$-ray analysis of single crystals of compound $\mathbf{8}$ obtained by crystallization from $\mathrm{CH}_{2} \mathrm{Cl}_{2}$ confirmed the structure of $\mathbf{8}$ to be that of 2-(4-aminophenyl)-4-ferrocenyl-6-methylpyrimidine (Figure 5). The Xray analysis data show that the N-C bonds in pyrimidine 8 have virtually equal lengths $[\mathrm{d}=1.347$ (5), 1.340 (5) $\AA$ ]. The lengths of Fe-C bonds and the geometry of the ferrocene sandwich are the same as in related compounds [19]. 
Scheme 3. Reaction of 3-ferrocenylmethylidene-2,4-pentanedione (1) with 4-aminobenzamidine (3a,b).

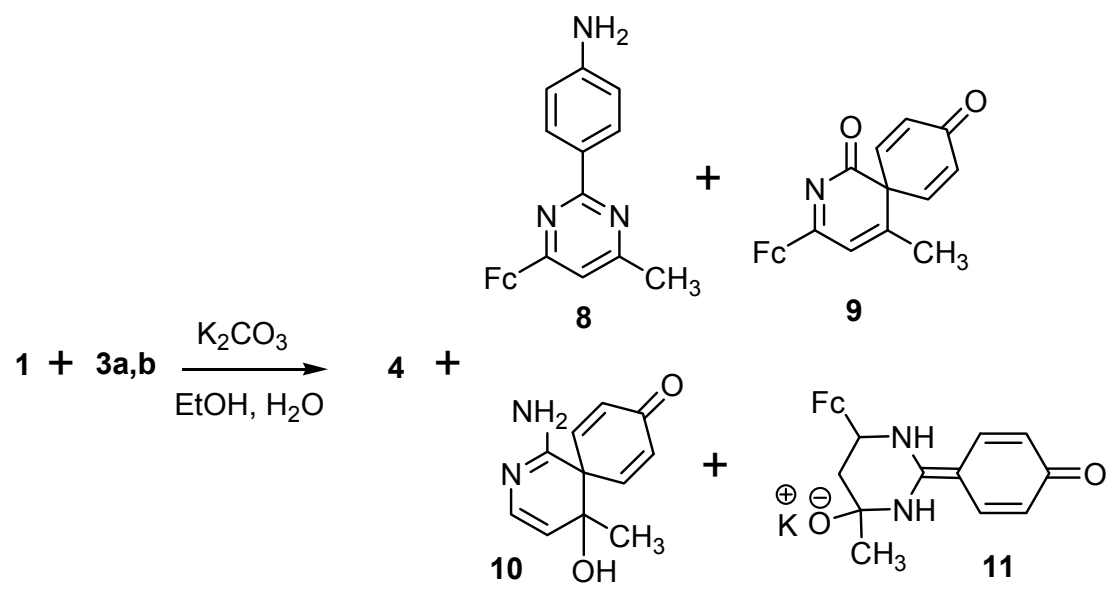

Figure 5. X-ray crystal structure of 8.

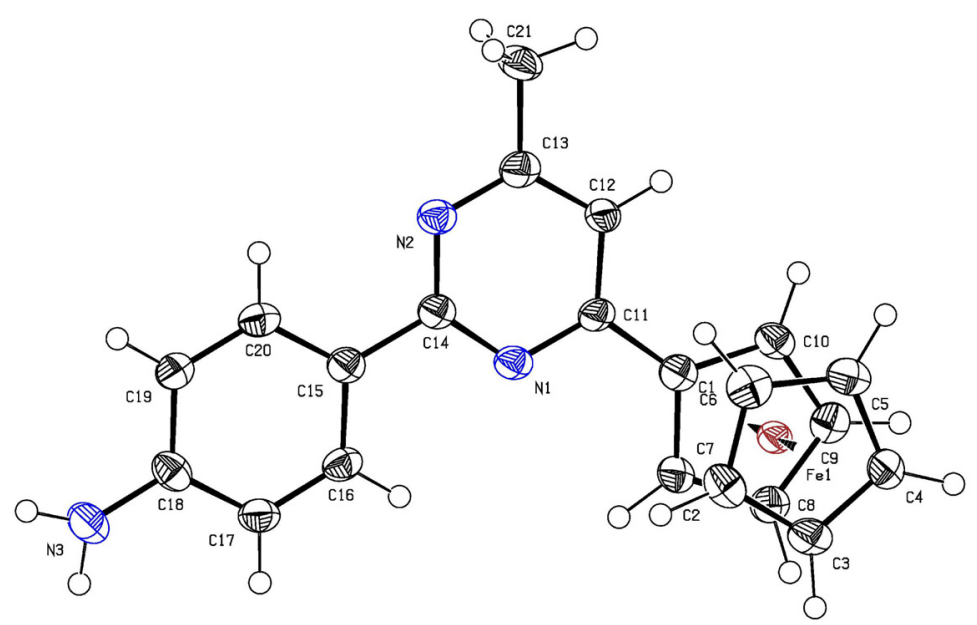

Compounds 9 and $\mathbf{1 0}$ are bright red powder substances, isolated in yields of about $10 \%-12 \%$. The IR spectra of compounds $\mathbf{9}$ and $\mathbf{1 0}$ contain the corresponding numbers of characteristic $\mathrm{C}=\mathrm{O}$ (compounds 9 and 10), $\mathrm{NH}_{2}$ and $\mathrm{OH}$ (compound 10), and $\mathrm{Fc}$ fragment absorption bands. The ${ }^{1} \mathrm{H}-\mathrm{NMR}$ spectra of compounds $\mathbf{9}$ and $\mathbf{1 0}$ contain signals from the unsubstituted cyclopentadienyl rings of ferrocene, together with signals from protons of substituted cyclopentadienyl rings, signals from methyl groups, from olefin protons (compounds 9 and 10), from hydroxyl and amine groups (compound 10), and semiquinoid substituents. Each of the ${ }^{13} \mathrm{C}$-NMR spectra contains one signal from the quaternary spiro carbon atoms with $\delta=48.31 \mathrm{ppm}$ and $47.28 \mathrm{ppm}$, one signal of $\mathrm{C}_{\mathrm{ipso}} \mathrm{Fc}$, and the corresponding numbers of signals from carbon atoms of carbonyl groups and quaternary carbons of the heterocycles. The mass spectra of compounds $\mathbf{9}$ and $\mathbf{1 0}$ contain peaks of molecular ions with $\mathrm{m} / \mathrm{z}=371$ and $378[\mathrm{M}]^{+}$, respectively; this fact also confirms the assumed structure.

Compound $\mathbf{1 1}$ is a yellow powder, which is soluble in water, methanol, and DMSO; it decomposes upon heating $\left(\sim 310^{\circ} \mathrm{C}\right)$. The mass spectrum of compound $\mathbf{1 1}$ contains the peak of a molecular ion with $m / z=429[\mathrm{M}]^{+}$. The IR spectrum of compound 11 contains the characteristic absorption bands of the $\mathrm{Fc}, \mathrm{C}=\mathrm{O}$, and $\mathrm{NH}$ groups. The ${ }^{1} \mathrm{H}$ and ${ }^{13} \mathrm{C}-\mathrm{NMR}$ spectroscopy data are provided in the Experimental section. As follows from the ${ }^{1} \mathrm{H}-\mathrm{NMR}$ spectra, compound $\mathbf{1 1}$ was obtained in the form of one 
diastereomer, presumably with a,e-trans-oriented Fc and Me groups. On the basis of our data and by analogy with the structure of potassium pyrimidoxide 7, product 11 was assumed to have the structure of potassium 6-ferrocenyl-4-methyl-2(4-oxo-2,5-cyclohexadienylidene)-hexahydropyrimid-4-oxide. Unfortunately, we failed to obtain single crystals of compound $\mathbf{1 1}$ that would be suitable for confirming its spatial structure by X-ray diffraction analysis.

The results of this study (Schemes 2 and 3) show that all heterocyclic compounds 5-7 and 8-11 were formed via fragmentation of the initial $\beta$-diketone into chalcone 4 , whose cyclocondensation with amidines $\mathbf{2 a}, \mathbf{b}$ and $\mathbf{3 a}, \mathbf{b}$ yielded products $\mathbf{5}-\mathbf{1 1}$. In this process, pyrimidines $\mathbf{5}$ and $\mathbf{8}$ were formed from tautomers $\mathbf{2 a}$ and $\mathbf{3 a}$, and compounds 6, 7, 9-11 were formed from tautomers $\mathbf{2 b}$ and $\mathbf{3 b}$, respectively.

To prove this statement, we studied the interaction of 4-ferrocenyl-3-buten-2-one $\mathbf{1}$ with amidines 2 and 3 under similar conditions $\left(\mathrm{EtOH} / \mathrm{H}_{2} \mathrm{O}, \mathrm{K}_{2} \mathrm{CO}_{3}, 80-82{ }^{\circ} \mathrm{C}\right)$ and found that enone under these conditions does not cyclocondense with amidines $\mathbf{2}$ and $\mathbf{3}$ (Scheme 4).

Scheme 4. Reaction of 4-ferrocenyl-3-buten-2-one (1) with amidines (2) and (3).

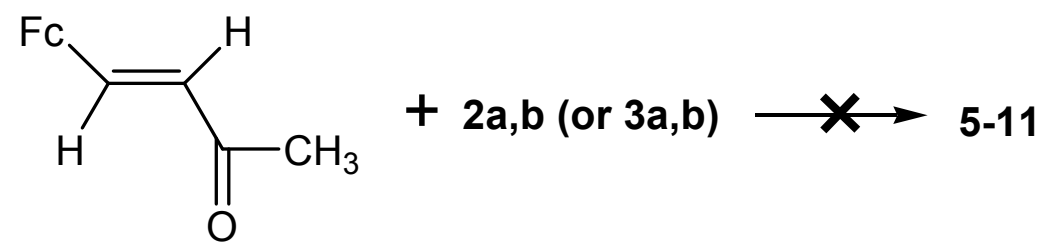

The reaction almost quantitatively yielded the initial chalcone 4 , even after boiling of the reaction mixture for $24 \mathrm{~h}$.

2.2. Posible Mechanisms of the Reactions of Acetamidine and p-Aminobenzamidine with 3-Ferrocenylmethylidene-2,4-pentanedione

On the basis of the results, we can make the following conclusions:

(1) Chalcone 4 is formed in the studied reactions as a result of one-pot nucleophilic attack of amidine nitrogens on the carbonyl carbon of the acetyl group in $\beta$-diketone $\mathbf{1}$ (Scheme 5a).

(2) Compounds 5-11 were formed in the three-component reaction with a simultaneous nucleophilic attack of two amidine molecules ( 2 or $\mathbf{3}$ ) on one $\beta$-diketone molecule. The presumable reaction mechanisms are shown in Schemes $5 \mathrm{~b}$ and $6 \mathrm{a}, \mathrm{b}$.

Schemes 5. Plausible mechanisms for the formation of compound 4 (a), compounds 5 and $8(\mathbf{b})$.

a

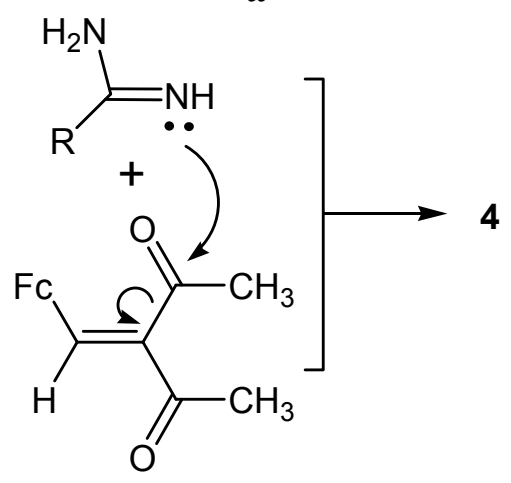

b

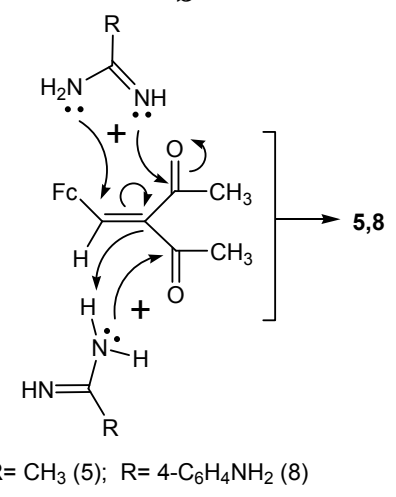


Schemes 6. Plausible mechanisms for the formation of compounds 6, 9, 10 (a), compounds 7 and $\mathbf{1 1}(\mathbf{b})$.

a

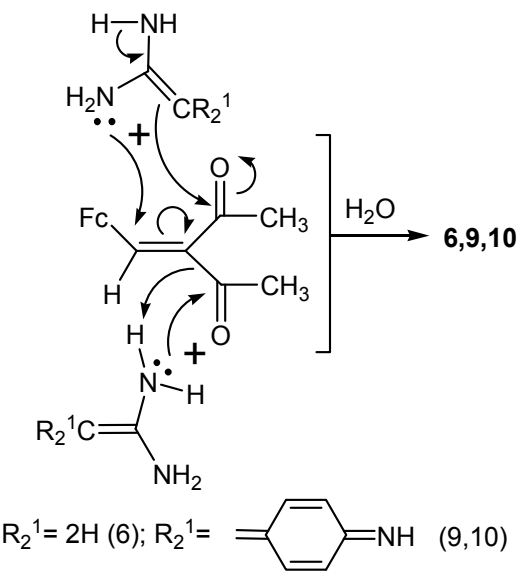

b

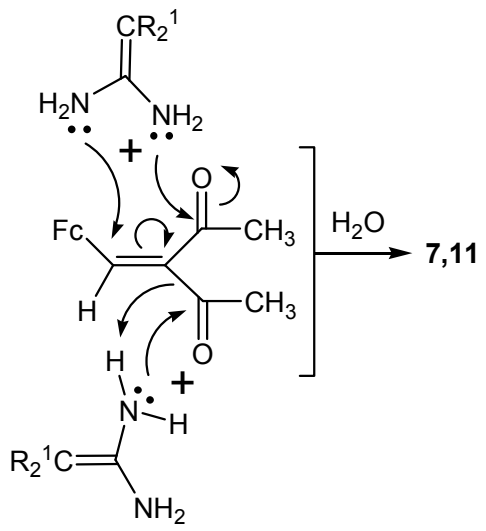

\section{Experimental}

\subsection{General}

Column chromatography was carried out on alumina (Brockmann activity III). The ${ }^{1} \mathrm{H}-$ and ${ }^{13} \mathrm{C}-\mathrm{NMR}$ spectra were recorded on a Unity Inova Varian spectrometer (300 and $75 \mathrm{MHz}$ ) for solutions in $\mathrm{CDCl}_{3}$ (for compounds 4-6 and 8-10) and $\mathrm{D}_{2} \mathrm{O}$ (for compounds 7 and 11), with $\mathrm{Me}_{4} \mathrm{Si}$ as the internal standard. The IR spectra were measured with a Perkin-Elmer Instruments Spectrum RXI FTIR spectrophotometer using $\mathrm{KBr}$ pellets. The mass spectra were obtained on a Varian MAT CH-6 instrument (EI MS, $70 \mathrm{eV}$ ). The melting pointa were determined with $\mathrm{w}$ micro melting point apparatus (Boëtius or Fisher) and the uncorrected values were used. An Elementar Analysensysteme LECO CHNS-900 apparatus was used for the elemental analyses. The following reagents were purchased from Aldrich (Toluca, Mexico): ferrocenecarbaldehyde, 99\%; acetylacetone, 99+\%; acetamidine hydrochloride, 95\%; 4-aminobenzamidine dihydrochloride, 95\%. 3-Ferrocenyl-methylidenepentane2,4-dione (1) was prepared by condensation of ferrocenecarbaldehyde with acetylacetone in benzene in the presence of piperidinium acetate. The physical and ${ }^{1} \mathrm{H}-\mathrm{NMR}$ spectroscopic characteristics of compound 1 were all in accordance with the literature data [18,20,21].

\subsection{Reactions of 3-Ferrocenylmethylidenepentane-2,4-dione (1) with Acetamidine Hydrochloride (2)}

(General Procedure)

A mixture of compound 1 (1.48 g, $5.0 \mathrm{mmol})$, acetamidine hydrochloride (2, $0.95 \mathrm{~g}, 10.0 \mathrm{mmol})$, ethanol $(60 \mathrm{~mL}), \mathrm{H}_{2} \mathrm{O}(10 \mathrm{~mL})$ and $\mathrm{K}_{2} \mathrm{CO}_{3}(1.4 \mathrm{~g})$ was stirred for $2 \mathrm{~h}$ at $80{ }^{\circ} \mathrm{C}$. The solvents were removed in vacuo, the residue mixed with dichloromethane $(50 \mathrm{~mL})$ and $\mathrm{Al}_{2} \mathrm{O}_{3}$ (activity III) $(20 \mathrm{~g})$. The solvent was evaporated in air. This sorbent was applied onto a column with $\mathrm{Al}_{2} \mathrm{O}_{3}$ (the height of alumina is $c a .20 \mathrm{~cm}$ ) and the reaction products were eluted from the column to afford the following reaction products: trans-4-ferrocenyl-3-buten-2-one (4, eluted with hexane-ether, 5:1), 4-ferrocenyl2,6-dimethylpyrimidine (5, eluted with hexane-ether, 2:1), 6-ferrocenyl-4-hydroxy-4-methyl-2-piperidone 
(6, eluted with hexane-dichloromethane, 2:1), potassium 6-ferrocenyl-4-methyl-2-methylidenhexahydro-4-pyrimidoxide (7, eluted with dichloromethane-methanol-water, 2:2:1).

Trans-4-ferrocenyl-3-buten-2-one (4). Red crystals, yield $0.32 \mathrm{~g} \mathrm{(25 \% ,} \mathrm{from} \mathrm{2),} 0.27 \mathrm{~g} \mathrm{(21 \% ,} \mathrm{from} \mathrm{3),}$ m.p. ${ }^{104-105}{ }^{\circ} \mathrm{C} .{ }^{1} \mathrm{H}-\mathrm{NMR}: 2.28\left(\mathrm{~s}, 3 \mathrm{H}, \mathrm{CH}_{3}\right), 4.14\left(\mathrm{~s}, 5 \mathrm{H}, \mathrm{C}_{5} \mathrm{H}_{5}\right), 4.14\left(\mathrm{~s}, 5 \mathrm{H}, \mathrm{C}_{5} \mathrm{H}_{5}\right), 4.43(\mathrm{~m}, 2 \mathrm{H}$, $\left.\mathrm{C}_{5} \mathrm{H}_{4}\right), 4.50\left(\mathrm{~m}, 2 \mathrm{H}, \mathrm{C}_{5} \mathrm{H}_{4}\right), 6.32(\mathrm{~d}, 1 \mathrm{H}, \mathrm{CH}=, J=15.9 \mathrm{~Hz}), 7.42(\mathrm{~d}, 1 \mathrm{H}, \mathrm{CH}=, J=15.9 \mathrm{~Hz})$

4-Ferrocenyl-2,6-dimethylpyrimidine (5). Orange crystals, yield 0.30 g (20\%), m.p. $120-121{ }^{\circ} \mathrm{C}$. IR (KBr): 491, 793, 820, 923, 1002, 1061, 1086, 1120, 1181, 1200, 1233, 1232, 1331, 1368, 1472, 1565, 1642, 1719, 2931, 2934, 2971, 3065, 3018, $3301 \mathrm{~cm}^{-1}$; ${ }^{1} \mathrm{H}-\mathrm{NMR}: 2.47$ (s, 3H, $\left.\mathrm{CH}_{3}\right), 2.67$ (s, 3H, $\left.\mathrm{CH}_{3}\right)$, $4.18\left(\mathrm{~s}, 5 \mathrm{H}, \mathrm{C}_{5} \mathrm{H}_{5}\right), 4.45\left(\mathrm{~m}, 2 \mathrm{H}, \mathrm{C}_{5} \mathrm{H}_{4}\right), 4.96\left(\mathrm{~m}, 2 \mathrm{H}, \mathrm{C}_{5} \mathrm{H}_{4}\right), 7.01(\mathrm{~s}, 1 \mathrm{H}, \mathrm{CH}=)$; ${ }^{13} \mathrm{C}-\mathrm{NMR}: 29.18$, $30.16\left(2 \mathrm{CH}_{3}\right), 69.58\left(\mathrm{C}_{5} \mathrm{H}_{5}\right), 69.83,71.12\left(\mathrm{C}_{5} \mathrm{H}_{4}\right), 88.75\left(\mathrm{C}_{i p s o} \mathrm{Fc}\right), 132.16(\mathrm{CH}=), 143.62,152.19,159.85$ (3C). MS: $m / z 292[\mathrm{M}]^{+}$. Anal. Calcd. for $\mathrm{C}_{16} \mathrm{H}_{16} \mathrm{FeN}_{2}$ : C 65.78, H 5.52, Fe 19.12, N 9.58. Found: C 65.69, H 5.38, Fe 19.23, N 9.68.

6-Ferrocenyl-4-hydroxy-4-methyl-2-piperidone (6). Yellow crystals, yield $0.36 \mathrm{~g}(23 \%)$, m.p. $147-148{ }^{\circ} \mathrm{C}$. IR (KBr): 512, 771, 805, 820, 953, 1002, 1045, 1079, 1103, 1147, 1198, 1223, 1309, 1348, 1376, 1489, 1571, 1668, 2956, 2980, 3324, $3429 \mathrm{~cm}^{-1}$; ${ }^{1} \mathrm{H}-\mathrm{NMR}: 1.36$ (s, 3H, $\left.\mathrm{CH}_{3}\right), 1.51\left(\mathrm{dd}, 1 \mathrm{H}, \mathrm{CH}_{2}\right.$, $J=11.7,13.2 \mathrm{~Hz}), 2.03\left(\mathrm{dd}, 1 \mathrm{H}, \mathrm{CH}_{2}, J=4.17,13.2 \mathrm{~Hz}\right), 2.12(\mathrm{bs}, 1 \mathrm{H}, \mathrm{OH}), 2.39$ (d, $1 \mathrm{H}, \mathrm{CH}_{2}$, $J=17.7 \mathrm{~Hz}), 2.50\left(\mathrm{~d}, 1 \mathrm{H}, \mathrm{CH}_{2}, J=17.7 \mathrm{~Hz}\right), 4.22\left(\mathrm{~s}, 5 \mathrm{H}, \mathrm{C}_{5} \mathrm{H}_{5}\right), 4.15\left(\mathrm{~m}, 1 \mathrm{H}, \mathrm{C}_{5} \mathrm{H}_{4}\right), 4.17(\mathrm{~m}, 2 \mathrm{H}$, $\left.\mathrm{C}_{5} \mathrm{H}_{4}\right), 4.21\left(\mathrm{~m}, 1 \mathrm{H}, \mathrm{C}_{5} \mathrm{H}_{4}\right), 4.54(\mathrm{dd}, 1 \mathrm{H}, \mathrm{CH}, J=4.16,11.7 \mathrm{~Hz}), 6.18$ (bs, $\left.1 \mathrm{H}, \mathrm{NH}\right) ;{ }^{13} \mathrm{C}-\mathrm{NMR}: 30.14$ $\left(\mathrm{CH}_{3}\right), 44.70,45.17\left(2 \mathrm{CH}_{2}\right), 64.63(\mathrm{CH}), 68.68\left(\mathrm{C}_{5} \mathrm{H}_{5}\right), 66.68,68.25,68.39,68.97\left(\mathrm{C}_{5} \mathrm{H}_{4}\right), 90.54$ $\left(\mathrm{C}_{\text {ipso }} \mathrm{Fc}\right), 49.07,171.26(2 \mathrm{C})$; MS: $m / z 313[\mathrm{M}]^{+}$. Anal. Calcd. for $\mathrm{C}_{16} \mathrm{H}_{19} \mathrm{FeNO}_{2}: \mathrm{C}$ 61.36, H 6.12, Fe 17.83, N 4.47. Found: C 61.18, H 6.16, Fe 17.79, N 4.58.

Potassium 6-ferrocenyl-4-methyl-2-methyliden-4-hexahydropyrimidoxide (7). Yellow crystals, yield 0.30 g (17\%), m.p. dec.ca $302{ }^{\circ} \mathrm{C}$. IR (KBr): 486, 502, 607, 771, 803, 821, 953, 1004, 1020, 1052, 1077, 1104, 1152, 1198, 1219, 1306, 1338, 1371, 1480, 1571, 1687, 2950, 2980, $3324 \mathrm{~cm}^{-1}$; ${ }^{1} \mathrm{H}-\mathrm{NMR}$ $\left(\mathrm{D}_{2} \mathrm{O}\right): 1.83$ (s, 3H, $\left.\mathrm{CH}_{3}\right), 2.21$ (t, $\left.1 \mathrm{H}, \mathrm{CH}_{2}, J=13.5 \mathrm{~Hz}\right), 2.43\left(\mathrm{dd}, 1 \mathrm{H}, \mathrm{CH}_{2}, J=3.9,13.5 \mathrm{~Hz}\right), 4.54$ $(\mathrm{dd}, 1 \mathrm{H}, \mathrm{CH}, J=3.9,13.5 \mathrm{~Hz}), 4.25\left(\mathrm{~s}, 5 \mathrm{H}, \mathrm{C}_{5} \mathrm{H}_{5}\right), 4.28\left(\mathrm{~m}, 1 \mathrm{H}, \mathrm{C}_{5} \mathrm{H}_{4}\right), 4.31\left(\mathrm{~m}, 1 \mathrm{H}, \mathrm{C}_{5} \mathrm{H}_{4}\right), 4.34(\mathrm{~m}$, $\left.1 \mathrm{H}, \mathrm{C}_{5} \mathrm{H}_{4}\right), 4.42\left(\mathrm{~m}, 1 \mathrm{H}, \mathrm{C}_{5} \mathrm{H}_{4}\right), 4.88(\mathrm{bs}, 1 \mathrm{H}, \mathrm{NH}), 4.93$ (bs, 1H, NH), 5.17 (d, 1H, $\left.\mathrm{CH}_{2}=, J=1.2 \mathrm{~Hz}\right)$, $5.31\left(\mathrm{~d}, 1 \mathrm{H}, \mathrm{CH}_{2}=, J=1.2 \mathrm{~Hz}\right) ;{ }^{13} \mathrm{C}-\mathrm{NMR}\left(\mathrm{D}_{2} \mathrm{O}\right): 18.19\left(\mathrm{CH}_{3}\right), 38.89,112.34\left(2 \mathrm{CH}_{2}\right), 46.63(\mathrm{CH})$, $68.75\left(\mathrm{C}_{5} \mathrm{H}_{5}\right), 65.91,68.04,68.15,69.04\left(\mathrm{C}_{5} \mathrm{H}_{4}\right), 76.87\left(\mathrm{C}_{i p s o} \mathrm{Fc}\right), 55.01,158.75(2 \mathrm{C}) ; \mathrm{MS}: \mathrm{m} / z 350$ $[\mathrm{M}]^{+}$. Anal. Calcd. for $\mathrm{C}_{16} \mathrm{H}_{19} \mathrm{FeKN}_{2} \mathrm{O}$ : C 54.88, H 5.47, N 7.99. Found: C 55.01, H 5.36, N 8.05.\%.

\subsection{Reactions of 3-Ferrocenylmethylidene-pentane-2,4-dione (1) with p-Aminobenzamidine} Dihydrochloride (3)

Following the general procedure, the reaction of $1(1.48 \mathrm{~g}, 5.0 \mathrm{mmol})$ with $p$-aminobenzamidine dihydrochloride $(3,2.07 \mathrm{~g}, 10.0 \mathrm{mmol})$ in a mixture of ethanol $(60 \mathrm{~mL})$ and $\mathrm{H}_{2} \mathrm{O}(10 \mathrm{~mL})$ in the presence of $\mathrm{K}_{2} \mathrm{CO}_{3}(3.0 \mathrm{~g})$ for $2 \mathrm{~h}$ at $80{ }^{\circ} \mathrm{C}$ afforded compounds 4 and 8-11.

2-(4-Aminophenyl)-4-ferrocenyl-6-methylpyrimidine (8). Orange crystals, yield $0.44 \mathrm{~g}$ (24\%), m.p. 153-154 ${ }^{\circ} \mathrm{C}$. IR (KBr): 483, 545, 593, 771, 824, 840, 1001, 1023, 1104, 1176, 1254, 1303, 1325, 1376, 
1438, 1489, 1522, 1570, 1585, 1621, 1725, 2854, 2924, 3082, 3096, 3210, 3364, $3459 \mathrm{~cm}^{-1}$; ${ }^{1} \mathrm{H}-\mathrm{NMR}$ : $2.53\left(\mathrm{~s}, 3 \mathrm{H}, \mathrm{CH}_{3}\right), 3.90\left(\mathrm{bs}, 2 \mathrm{H}, \mathrm{NH}_{2}\right), 4.07\left(\mathrm{~s}, 5 \mathrm{H}, \mathrm{C}_{5} \mathrm{H}_{5}\right), 4.47\left(\mathrm{~m}, 2 \mathrm{H}, \mathrm{C}_{5} \mathrm{H}_{4}\right), 5.05\left(\mathrm{~m}, 2 \mathrm{H}, \mathrm{C}_{5} \mathrm{H}_{4}\right)$, $6.77\left(\mathrm{~d}, 2 \mathrm{H}, \mathrm{C}_{6} \mathrm{H}_{4}, J=8.7 \mathrm{~Hz}\right), 6.97(\mathrm{~s}, 1 \mathrm{H}, \mathrm{CH}=), 8.36\left(\mathrm{~d}, 2 \mathrm{H}, \mathrm{C}_{6} \mathrm{H}_{4}, J=8.7 \mathrm{~Hz}\right) ;{ }^{13} \mathrm{C}-\mathrm{NMR}: 24.56$ $\left(\mathrm{CH}_{3}\right), 70.01\left(\mathrm{C}_{5} \mathrm{H}_{5}\right), 68.09,70.77\left(\mathrm{C}_{5} \mathrm{H}_{4}\right), 81.52\left(\mathrm{C}_{i p s o} \mathrm{Fc}\right), 112.69(\mathrm{CH}=), 114.72,129.88\left(\mathrm{C}_{6} \mathrm{H}_{4}\right)$, 128.87, 148.70, 163.99, 165.97, 167.16 (5C); MS: m/z $369[\mathrm{M}]^{+}$. Anal. Calcd. for $\mathrm{C}_{21} \mathrm{H}_{19} \mathrm{FeN}_{3}: \mathrm{C}$ 68.31, H 5.19, N 11.38. Found: C 68.32, H 5.17, N 11.26.

3-Ferrocenyl-5-methyl-2-azaspiro[5.5] undeca-2,4,7,10-tetraen-1,9-dione (9). Orange crystals, yield

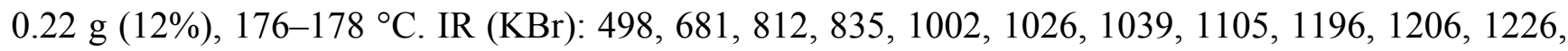
1280, 1301, 1344, 1394, 1441, 1469, 1519, 1547, 1575, 1599, 1622, 1698, 1705, 2949, 3197, 3210, $3345 \mathrm{~cm}^{-1}$; ${ }^{1} \mathrm{H}-\mathrm{NMR}: 2.13\left(\mathrm{~s}, 3 \mathrm{H}, \mathrm{CH}_{3}\right), 4.21\left(\mathrm{~s}, 5 \mathrm{H}, \mathrm{C}_{5} \mathrm{H}_{5}\right), 4.25\left(\mathrm{~m}, 2 \mathrm{H}, \mathrm{C}_{5} \mathrm{H}_{4}\right), 4.39\left(\mathrm{~m}, 2 \mathrm{H}, \mathrm{C}_{5} \mathrm{H}_{4}\right)$, $6.71\left(\mathrm{~d}, 2 \mathrm{H}, \mathrm{C}_{6} \mathrm{H}_{4}, J=8.7 \mathrm{~Hz}\right), 7.41(\mathrm{~s}, 1 \mathrm{H}, \mathrm{CH}=), 7.52\left(\mathrm{~d}, 2 \mathrm{H}, \mathrm{C}_{6} \mathrm{H}_{4}, J=8.7 \mathrm{~Hz}\right) ;{ }^{13} \mathrm{C}-\mathrm{NMR}: 29.64$ $\left(\mathrm{CH}_{3}\right), 69.18\left(\mathrm{C}_{5} \mathrm{H}_{5}\right), 68.87,69.96\left(\mathrm{C}_{5} \mathrm{H}_{4}\right), 89.71\left(\mathrm{C}_{i p s o} \mathrm{Fc}\right), 113.11(\mathrm{CH}=), 121.42,131.33\left(\mathrm{C}_{6} \mathrm{H}_{4}\right)$, 48.31, 58.45, $132.21,154.34,154.89$ (5C); MS: $m / z$ 371 [M] $]^{+}$. Anal. Calcd. for $\mathrm{C}_{21} \mathrm{H}_{17} \mathrm{FeNO}_{2}$ : C 67.94, H 4.62, N 3.77. Found: C 68.03, H 4.75, N 3.69.

1-Amino-3-ferrocenyl-5-hydroxy-5-methyl-2-azaspiro[5.5] undeca-1,3,7,10-tetraen-9-one (10). Orange crystals, yield $0.25 \mathrm{~g}(13 \%)$, m.p. $181-182{ }^{\circ} \mathrm{C}$. IR (KBr): 486, 559, 725, 822, 842, 998, 1001, 1043, $1109,1197,1231,1256,1273,1328,1379,1445,1520,1557,1595,1608,1646,1684,1725,2967$, 3091, 3208, 3352, $3461 \mathrm{~cm}^{-1}$; ${ }^{1} \mathrm{H}-\mathrm{NMR}: 1.98$ (s, 3H, $\left.\mathrm{CH}_{3}\right), 2.48$ (bs, $\left.1 \mathrm{H}, \mathrm{OH}\right), 4.23\left(\mathrm{~s}, 5 \mathrm{H}, \mathrm{C}_{5} \mathrm{H}_{5}\right), 4.17$ $\left(\mathrm{m}, 2 \mathrm{H}, \mathrm{C}_{5} \mathrm{H}_{4}\right), 4.27\left(\mathrm{~m}, 2 \mathrm{H}, \mathrm{C}_{5} \mathrm{H}_{4}\right), 5.03-5.23\left(\mathrm{bs}, 2 \mathrm{H}, \mathrm{NH}_{2}\right), 6.22(\mathrm{~s}, 1 \mathrm{H}, \mathrm{CH}=), 6.65\left(\mathrm{~d}, 2 \mathrm{H}, \mathrm{C}_{6} \mathrm{H}_{4}\right.$, $J=7.8 \mathrm{~Hz}), 7.55\left(\mathrm{~d}, 2 \mathrm{H}, \mathrm{C}_{6} \mathrm{H}_{4}, J=7.8 \mathrm{~Hz}\right) ;{ }^{13} \mathrm{C}-\mathrm{NMR}: 18.96\left(\mathrm{CH}_{3}\right), 68.58\left(\mathrm{C}_{5} \mathrm{H}_{5}\right), 66.02,66.77,67.90$, $68.21\left(\mathrm{C}_{5} \mathrm{H}_{4}\right), 90.93\left(\mathrm{C}_{\text {ipso }} \mathrm{Fc}\right), 103.89(\mathrm{CH}=), 112.95,130.21\left(\mathrm{C}_{6} \mathrm{H}_{4}\right), 47.28,59.01,130.19$, 153.11, 153.56 (5C); MS: $m / z 388$ [M] $]^{+}$. Anal. Calcd. for $\mathrm{C}_{21} \mathrm{H}_{20} \mathrm{FeN}_{2} \mathrm{O}_{2}$ : C 64.97, H 5.19, N 7.21. Found: C 64.84, H 5.23, N 7.30 .

Potassium 6-ferrocenyl-4-methyl-2-(4-oxo-2,5-cyclohexadienyliden)-4-hexahydropyrimidoxide (11). Yellow powder, yield $0.39 \mathrm{~g}(18 \%)$, m.p. dec.ca $298^{\circ} \mathrm{C}$. IR (KBr): 486, 553, 612, 715, 819, 913, 1000, 1026, 1078, 1102, 1201, 1272, 1337, 1421, 1432, 1478, 1557, 1631, 1689, 1714, 2861, 2929, 3046, $3323 \mathrm{~cm}^{-1}$; ${ }^{1} \mathrm{H}-\mathrm{NMR}: 1.85$ (s, 3H, $\left.\mathrm{CH}_{3}\right), 2.09$ (t, $\left.1 \mathrm{H}, \mathrm{CH}_{2}, J=13.2 \mathrm{~Hz}\right), 2.56\left(\mathrm{dd}, 1 \mathrm{H}, \mathrm{CH}_{2}, J=4.2\right.$, $13.2 \mathrm{~Hz}), 4.83(\mathrm{dd}, 1 \mathrm{H}, \mathrm{CH}, J=4.2,13.2 \mathrm{~Hz}), 4.23\left(\mathrm{~s}, 5 \mathrm{H}, \mathrm{C}_{5} \mathrm{H}_{5}\right), 4.24\left(\mathrm{~m}, 2 \mathrm{H}, \mathrm{C}_{5} \mathrm{H}_{4}\right), 4.45(\mathrm{~m}, 2 \mathrm{H}$, $\left.\mathrm{C}_{5} \mathrm{H}_{4}\right), 5.98-6.05$ (bs, 2H, 2NH), $6.64\left(\mathrm{~d}, 2 \mathrm{H}, \mathrm{C}_{6} \mathrm{H}_{4}, J=8.7 \mathrm{~Hz}\right), 7.39$ (d, 2H, $\left.\mathrm{C}_{6} \mathrm{H}_{4}, J=8.7 \mathrm{~Hz}\right)$;

${ }^{13} \mathrm{C}-\mathrm{NMR}: 19.01\left(\mathrm{CH}_{3}\right), 46.17\left(\mathrm{CH}_{2}\right), 50.07(\mathrm{CH}), 68.68\left(\mathrm{C}_{5} \mathrm{H}_{5}\right), 66.05,67.85,68.03,69.40\left(\mathrm{C}_{5} \mathrm{H}_{4}\right)$, $85.13\left(\mathrm{C}_{i p s o} \mathrm{Fc}\right), 112.62,130.11\left(\mathrm{C}_{6} \mathrm{H}_{4}\right), 55.03,130.88,142.12,167.51(4 \mathrm{C})$; MS: $m / z 388[\mathrm{M}]^{+}$. Anal. Calcd. for $\mathrm{C}_{21} \mathrm{H}_{21} \mathrm{FeKN}_{2} \mathrm{O}_{2}$ : C 58.76, H4.93, N 6.53. Found: C 58.87, H 5.01, N 6.42.

\subsection{Crystal Structures of $\mathbf{6}, \mathbf{7}$ and $\mathbf{8}$}

Single crystals of $\mathbf{6}$ and $\mathbf{8}$ were obtained by crystallization from $\mathrm{CH}_{2} \mathrm{Cl}_{2}$, while crystals of 7 were obtained by crystallization from $\mathrm{H}_{2} \mathrm{O}$. The unit cell parameters and the X-ray diffraction intensities of 6, 7 and 8 were recorded on a Gemini (detector Atlas CCD, Cryojet $\mathrm{N}_{2}$ ) diffractometer. The crystallographic data, the parameters of the X-ray diffraction experiments, and refinements are listed in 
supplementary Table S2. The structure of compounds 6-8 were solved by the direct method (SHELXS-97 [22]) and refined using full-matrix least-squares on $F^{2}$.

Crystal data for $\mathrm{C}_{16} \mathrm{H}_{19} \mathrm{FeNO}_{2}(6): \mathrm{M}=313.17 \mathrm{~g} \cdot \mathrm{mol}^{-1}$, orthorhombic P b c a, $a=10.5206(6)$, $b=10.1711(5), c=25.8276(12) \AA, \alpha=90, \beta=90, \gamma=90^{\circ}, \mathrm{V}=2763.7(2) \AA^{3}, \mathrm{~T}=130(2) \mathrm{K}, \mathrm{Z}=8$, $\rho=1.505 \mathrm{Mg} / \mathrm{m}^{3}$, wavelength $0.71073 \AA, \mathrm{F}(000)=1312$, absorption coefficient $1.091 \mathrm{~mm}^{-1}$, scan range $3.66 \leq \theta \leq 26.05^{\circ}, 2713$ independent reflections, $\mathrm{R}_{\text {int }}=0.0663,20243$ total reflections, 188 refinable parameters, final $\mathrm{R}$ indices $[\mathrm{I}>2 \sigma(\mathrm{I})] \mathrm{R}_{1}=0.0343, \mathrm{wR}_{2}=0.0677, \mathrm{R}$ indices (all data) $\mathrm{R}_{1}=0.0558$, $\mathrm{wR}_{2}=0.0763$, goodness-of-fit on $\mathrm{F}^{2} 1.087$, largest difference peak and hole $0.333 /-0.318 \mathrm{e} \AA^{-3}$.

Crystal data for $\mathrm{C}_{32} \mathrm{H}_{38} \mathrm{Fe}_{2} \mathrm{~K}_{2} \mathrm{~N}_{4} \mathrm{O}_{2}$ (7): $\mathrm{M}=700.56 \mathrm{~g} \cdot \mathrm{mol}^{-1}$, monoclinic P21/c, $a=10.5530(5)$, $b=9.8630(5), c=15.1210(7) \AA, \alpha=90, \beta=101.702(5), \gamma=90^{\circ}, \mathrm{V}=1541.15(13) \AA^{3}, \mathrm{~T}=130(2) \mathrm{K}$, $\mathrm{Z}=2, \rho=1.510 \mathrm{Mg} / \mathrm{m}^{3}$, wavelength $0.71073 \AA, \mathrm{F}(000)=728$, absorption coefficient $1.248 \mathrm{~mm}^{-1}$, scan range $3.34 \leq \theta \leq 26.13^{\circ}, 3041$ independent reflections, $\mathrm{R}_{\text {int }}=0.0830,11105$ total reflections, 199 refinable parameters, final $\mathrm{R}$ indices $[\mathrm{I}>2 \sigma(\mathrm{I})] \mathrm{R}_{1}=0.0555, \mathrm{wR}_{2}=0.1266, \mathrm{R}$ indices (all data) $\mathrm{R}_{1}=0.0993$, $\mathrm{wR}_{2}=0.1357$, goodness-of-fit on $\mathrm{F}^{2} 1.008$, largest difference peak and hole $0.814 /-0.789 \mathrm{e}^{-3}$.

Crystal data for $\mathrm{C}_{21} \mathrm{H}_{19} \mathrm{FeN}_{3}(\mathbf{8}): \mathrm{M}=369.24 \mathrm{~g} \cdot \mathrm{mol}^{-1}$, monoclinic P21/c, $a=11.0190(5), b=14.3412(5)$, $c=12.1698(4) \AA, \alpha=90, \beta=101.661(4), \gamma=90^{\circ}, \mathrm{V}=1883.45(12) \AA^{3}, \mathrm{~T}=293(2) \mathrm{K}, \mathrm{Z}=4$, $\rho=1.302 \mathrm{Mg} / \mathrm{m}^{3}$, wavelength $1.54180 \AA, \mathrm{F}(000)=768$, absorption coefficient $6.460 \mathrm{~mm}^{-1}$, scan range $4.10 \leq \theta \leq 66.59^{\circ}, 3317$ independent reflections, $\mathrm{R}_{\text {int }}=0.0839,11651$ total reflections, 233 refinable parameters, final $\mathrm{R}$ indices $[\mathrm{I}>2 \sigma(\mathrm{I})] \mathrm{R}_{1}=0.0431, \mathrm{wR}_{2}=0.1652, \mathrm{R}$ indices (all data) $\mathrm{R}_{1}=0.0768$, $\mathrm{wR}_{2}=0.1779$, goodness-of-fit on $\mathrm{F}^{2} 0.979$, largest difference peak and hole $1.419 /-0.539 \mathrm{e} \AA^{-3}$.

CCDC-927702 (for 6), CCDC-927704 (for 7) and CCDC-927703 (for 8) contain the supplementary crystallographic data for this paper. This data can be obtained free of charge at www.ccdc.cam.ac.uk/const/retrieving.html [or from the Cambridge Crystallographic Data Centre, 12, Union Road, Cambridge DB2 1EZ, UK; Fax: (internat.) +44 1223/336 033; E-mail: deposit@ccdc.cam.ac.uk].

\section{Conclusions}

Thus, it has been found that the two tautomeric forms (amidoimine and ene-1,1-diamine) of acetamidine (2) and $p$-aminobenzamidine (3) react with 3-ferrocenylmethylidene-2,4-pentanedione (1). Such an observation has been made for the first time. Two processes take place during the reaction: fragmentation of $\beta$-diketone $\mathbf{1}$ into $\beta$-ferrocenylvinyl(methyl)ketone $\mathbf{4}$ and three-component cyclocondensation-fragmentation, which leads to simultaneous formation of mixtures of ferrocenylpyrimidine and piperidone derivatives 5-11, including spiro compounds (9, 10), and polymeric coordination compounds: potassium hexahydropyrimidoxides $(\mathbf{7}, \mathbf{1 1})$. The results are so unexpected that they surely deserve more detailed investigation using a broader spectrum of reagents, in order to have more opportunities for practical studies of such processes. Synthesis of stable polymeric complexes of alkaline metals and studies of their physicochemical, biological, etc. properties are of special interest. 


\section{Supplementary Materials}

Supplementary materials can be accessed at: http://www.mdpi.com/1420-3049/19/01/0041/s1.

\section{Acknowledgements}

Financial support from DGAPA-UNAM, Mexico (PAPIIT grant IN-211112 and PASPA program) is gratefully acknowledged. Thanks are due to E. A. Vázquez López for his technical assistance.

\section{Conflicts of Interest}

The authors declare no conflict of interest.

\section{References}

1. Metallocenes; Togni, A., Halterman, R.L., Eds.; Wiley-VCH: New York, NY, USA, 1998; Volume 1, Chapter 1.

2. Stepnicka, P. Ferrocenes.: Ligands., Materials and Biomolecules; John Wiley \& Sons, Ltd.: Chichester, UK, 2008.

3. Bildstein, B.; Skibar, W.; Schweiger, M.; Kopacka, H.; Wurst, K. In situ synthesis of the first $\mathrm{C}_{7}$ cumulene $(\mathrm{Fc})_{2} \quad \mathrm{C}=\mathrm{C}=\mathrm{C}=\mathrm{C}=\mathrm{C}=\mathrm{C}=\mathrm{C}(\mathrm{Fc})_{2}$ via deprotonation of its conjugate acid $\left[(\mathrm{Fc})_{2} \mathrm{C}_{7} \mathrm{H}(\mathrm{Fc})_{2}\right]^{+} \mathrm{BF}_{4}^{-}$(Fc-ferrocenyl). J. Organomet. Chem. 2001, 622, 135-142.

4. Kaifer, A.E.; Mendoza, S. Comprehensive Supramolecular Chemistry; Elsevier: Oxford, UK, 1996; Volume 1.

5. Heo, R.W.; Somoza, F.B.; Lee, T.R. Soluble conjugated polymers that contain ferrocenylene units in the backbone. J. Am. Chem. Soc. 1998, 120, 1621-1622.

6. Tolbert, L.M.; Zhao, X.; Ding, Y.; Bottomley, L.A. Bis(ferroceny1)polymethine cations. A prototype molecular wire with redox-active end groups. J. Am. Chem. Soc. 1995, 117, 12891-12892.

7. Schvekhgeimer, M.-G.A. Heterylferrocenes. Synthesis and use. Russ. Chem. Rev. 1996, 65, 41-79.

8. Klimova, E.I.; Ruíz-Ramírez, L.; Martínez-García, M.; Meleshonkova, N.N. Synthesis of biologically active compounds based on 2-ferrocenylmethylene-3-quinuclidone. Russ. Chem. Bull. 1996, 45, 2602-2609.

9. Snegur, L.V.; Boev, V.I.; Yu, S.N.; Ilyin, M.M.; Davankov, V.A.; Starikova, Z.A.; Yanovsky, A.I.; Kolomiets, A.F.; Babin, V.N. Synthesis and structure of biologically active ferrocenylalkyl polyfluoro benzimidazoles. J. Organomet. Chem. 1999, 580, 26-35.

10. Klimova, E.; Klimova, T.; Ramírez, A.T.; Nieto, C.A.; Moreno, E.R.; Zea, C.D.; Martínez-García, M. Synthesis of 3-Ferrocenyl-3,3a,4,5-tetrahydro-2H-benzo[g]indazoles. Heterocycles 2004, 63, 1045-1056.

11. Vázquez, L.E.A.; Klimova, E.; Klimova, T.; Álvarez, T.C.; Ruíz, R.L.; Toscano, R.A.; Martínez, G.M. Synthesis of ferrocenyl-1-(4-pyridylmethyl)- and ferrocenyl-1-[2-hydroxy-1,2bis(4-pyridyl)ethyl]pyrazoles. Synthesis 2004, 15, 2471-2478.

12. Klimova, E.I.; Vázquez, L.E.A.; Klimova, T.; Álvarez, T.C.; Toscano, R.A.; Martínez, G.M. Synthesis of ferrocenylpyrazole derivatives. J. Heterocycl. Chem. 2005, 42, 265-271. 
13. Martínez, M.J.M.; Vázquez, L.E.A.; Moreno, E.R.; Flores-Alamo, M.; Klimova, E.I. Formation of pyridazino[4,5-c]pyridazine derivatives upon [4+2]-cycloaddition of 4-phenyl-1,2,4-triazoline-3,5dione to cross-conjugated monoferrocenyltrienes. J. Heterocycl. Chem. 2006, 43, 1115-1121.

14. Ratković, Z.; Juranić, Z.D.; Stanojković, T.; Manojlović, D.; Vukićević, R.D.; Radulović, N.; Joksović, M.D. Synthesis, Characterization, Electrochemical studies and antitumor activity of some new chalcone analogues containing ferrocenyl pyrazole moiety. Bioorg. Chem. 2010, 38, $26-32$.

15. Parveen, H.; Hayat, F.; Salahuddin, A.; Azarn, A. Synthesis, characterization and biological evaluation of novel 6-ferrocenyl-4-aryl-2-substituted pyrimidine derivatives. Eur. J. Med. Chem. 2010, 45, 3497-3503.

16. Klimova, E.I.; Sánchez, G.J.J.; Klimova, T.; Ramírez, A.T.; Vázquez, L.E.A.; Flores-Alamo, M.; Martínez, G.M. Synthesis and biological evaluation of novel ethyl 2-amino-6-ferrocenyl-1,6dihydropyrimidine-5-carboxylates and ethyl 2-amino-6-ferrocenylpyrimidine-5-carboxylates. J. Organomet. Chem. 2012, 708-709, 37-45.

17. Klimova, E.I.; Sotelo Dominguez, V.H.; Sánchez, G.J.J.; Klimova, T.; Backinowsky, L.V.; Flores-Alamo, M.; Martínez, G.M. 1,3-Insertion of amidines into ethyl E-2-acyl-3ferrocenylacrylates. Mendeleev. Commun. 2011, 21, 1-3.

18. Klimova, E.I.; Klimova, T.; Flores-Alamo, M.; Méndez, S.J.M.; Ruiz, R.L.; Backinowsky, L.V.; Martínez, G.M. The formation of 3-ferrocenylpyrazole-4-carboxylates and alkylhydrazine insertion products from $\alpha$-ferrocenylmethylidene- $\beta$-oxocarboxylates. J. Heterocycl. Chem. 2011, $48,441-448$.

19. Postnov, V.N.; Klimova, E.I.; Pushin, A.N.; Meleshonkova, N.N. The interaction of the 1,3-bis-(pmethoxyphenyl)allylic cation with ferrocenyl-1,3-butadienes. Metalloorg. Khim. 1992, 5, 564-569.

20. Postnov, V.N.; Polivin, Y.N.; Sazonova, V.A. Fragmentation of $\beta$-dicarbonyl compounds with ferrocenyl group. Dokl. Akad. Nauk. SSSR 1983, 271, 1402-1404.

21. Chang, C.H.; Porter, R.F.; Bauer, S.H. Structures of azomethane, 1,1,1-trifluoroazomethane, and hexafluoroazomethane, determined by electron diffraction. J. Am. Chem. Soc. 1970, 92, 5313-5318.

22. Sheldrick, G.M. SHELXS-97, Program for the Refinement of Crystal Structures; University of Göttingen: Göttingen, Germany, 1994.

Sample Availability: Samples of the compounds 6-8 are available from the authors.

(C) 2013 by the authors; licensee MDPI, Basel, Switzerland. This article is an open access article distributed under the terms and conditions of the Creative Commons Attribution license (http://creativecommons.org/licenses/by/3.0/). 